\title{
RÄTTSSÄKERHETEN OCH DE NYA BROTTSUNDERSÖKNINGSMETODERNA
}

\author{
Av Hans HolmÉr
}

Vi har valt att begränsa framställningen till några av de vanligaste och samtidigt mest diskuterade metoderna. I huvudsak görs också bedömningarna på basis av rättsläget i Sverige.

De s k okonventionella spaningsmetoderna är avsedda för att komma åt mycket grov brottslighet. I och för sig bör i stort sett alla metoder som inte är förbjudna i grundlagen kunna begagnas för det ändamålct. Men det är här också en fråga om vilken typ av polisväsende vi vill ha. Om den laglydiga medborgaren får klart för sig - eller bara får för sig - att polisen använder metoder som i vanliga fall är förbjudna eller gör sådant som sätter den personliga integriteten i fara kan han lätt förlora förtroendet för polisen. Och utan allmänhetens förtroende kan inte polisen fungera. Härtill kommer att nya metoder och medel ständigt möts av nya åtgärder för att neutralisera deras effekter. Det blir alltså fråga om en ständig upptrappning av kampen mellan polisen och brottslingarna. Det finns också en risk för att en metod som tillåts för viss mycket grov brottslighet kommer att föras över till andra områden. En polis som t ex vant sig vid att använda en metod för att upptäcka och säkra bevisning om narkotikabrott kan ha svårt att förstå varför han skall avstå från metoden när han placeras om till att exempelvis utreda inbrottsstölder.

Härtill kommer att åtskilliga av de nya metoderna är mycket resurskrävande och lätt blockerar andra insatser. Effekten av dem torde trots detta ofta vara ganska marginell. Det är visserligen klart att en del av de s k okonventionella spaningsmetoderna ändå bör komma till användning. Av det anförda framgår dock att det finns stora begränsningar i möjligheten att med dem komma till några revolutionerande resultat.

Traditionellt polisarbete bedrivs med relativt enkla metoder. Det brukar framför allt vara fråga om att höra personer som är inblandade och andra som kan ha gjort iakttagelser eller eljest har upplysningar att lämna. Polisen kan också genom att undersöka brottsplatser o d föra en utredning framåt. Vad gäller traditionell brottslighet som stölder, misshandel och liknande är den brottsanmälan som målsäganden gör det utan jämförelse viktigaste underlaget för brottsutredningen. Om den som gör anmälan kan ge upplysningar om miss- 
tänkt person, är chansen för att brottet skall klaras upp rätt stor. Annars är den liten.

Det är utmärkande för polisens arbete mot den traditionella brottsligheten att spaning och utredning inte börjar förrän det finns misstanke om att ett brott har begåtts, i regel genom att den som utsatts för brottet har gjort anmälan. De metoder polisen begagnar är fö $r$ det mesta helt öppna.

Vissa typer av modern brottslighet skiljer sig på viktiga punkter från traditionella brott. Modern brottslighet är offerlös i den meningen att det inte finns någon målsägande som är direkt drabbad av brottet och gör anmälan. Modern brottslighet drivs också ofta $\mathrm{i}$ mer organiserade och planmässiga former och på ett sätt som gör den svår att iaktta.

Modern brottslighet kräver bl a av dessa skäl i högre grad än traditionell att polisen utvecklar egna metoder och initiativ. Ibland kan det bli fråga om samarbete med andra myndigheter som har en tillsynsskyldighet e d såsom länsstyrelsena. Ofta beror emellertid upptäckten av sådana brott på polisens egna aktiviteter såsom vid trafikkontroller. I sådana fall medför upptäckten av brottet i regel också att man finner gärningsmannen.

Modern brottslighet har lett till ett behov av att begagna delvis nya metoder för att bekämpa brott. Allt eftersom brottslighet bedrivs i mer medvetna och planmässiga former och på ett sätt där man aktivt strävar efter att hindra insyn, fordras det att också polisen utvecklar strategier som inte behöver användas vid traditionclla brott. Dessa strategier har delvis hämtats från vad som sedan rätt lång tid utnyttjas vid brott mot rikets säkerhet o d. På senare tid är det framför allt kampen mot narkotikabrottsligheten som har varit drivkraften för denna utveckling. I många fall har de polismetoder som sålunda utvecklats också förbehållits arbetet med narkotikabrott och brott mot rikets säkerhet. Rent lagtekniskt har specialregleringar varit vanliga.

Typiskt sett kan tre sinsemellan något olika polisstrategier urskiljas.

En är att systematiskt samla och bearbeta upplysningar av olika slag om t ex personer och företeelser. Dessa upplysningar behöver inte röra brottslig verksamhet utan kan vara av mycket olika slag. Därigenom kan man fă dels en allmänn överblick över i vilka former brottsligheten bedrivs, dels mer konkreta uppslagsändar i enskilda brottsutredningar eller för att inleda sådana. Detta underrättelseförfarande som delvis bedrivs med hjälp av modern teknik är en i hög grad internationell företeelse.

För det andra har man i större utsträckning börjat använda tekniska hjälpmedel vid spaning och utredning av brott. En viktig sådan metod är telefonavlyssning. Polisen har också i allt högre utsträckning börjat utnyttja mer avancerade kameror och liknande materiel i sin spaning. Det har också förekommit att svensk polis har använt kroppsmikrofoner. 
En tredje metod som har kommit att utvecklas är att på olika sätt »spela med« och därigenom få användbara upplysningar eller bevis mot personer som har begått $t$ ex narkotikabrott. Det har sedan länge förekommit att polisen $i$ hemlighet făr upplysningar från personer som själva rör sig i miljöer där brott begås. Det händer också att poliser uppträder anonymt och genom infiltration försöker samla värdefull information.

Frågan om i vilken riktning och i vilken utsträckning polisen bör utveckla och begagna moderna, okonventionella metoder för spaning och utredning är kontroversiell.

Det tycks å ena sidan råda en rätt bred enighet om att polisen måsta utveckla sina metoder för att komma åt den mer avancerade brottsligheten. Och ingen bestrider att $t$ ex telefonavlyssning har gett god utdelning. Det står å andra sidan klart att många av de moderna metoderna reser allvarliga problem som ytterst rör polisens ställning och befogenheter i en rättsstat och medborgarnas anspråk på integritet.

Det är svårt att bedöma vilka effekter det på längre sikt kan få på samhällsklimatet och på medborgarnas förhållande och tilltro till polisen, om polisen i stor utsträckning tillåts operera dolt och samla iakttagelser av alla möjliga slag om människor. Sådana farhågor kan vara grundade alldeles oavsett om moderna metoder missbrukas eller inte. Ett annat problem är hur bruket av de moderna metoderna skall kontrolleras och av vem. När en viss metod väl har godtagits, kan man inte utan vidare utgå från att en aldrig så formellt fulländad kontroll, $t$ ex av domstol, i realiteten blir verkningsfull.

Man måsta vidare fråga sig vilka risker det finns för korruption och annat missbruk, företeelser som vi i Norden hittills tycks ha varit förskonade från men som har skakat polisorganisationer i andra länder. Sådana risker kan visserligen finnas oavsett vilka metoder som polisen får använda. Men det är möjligt att de ökar ju större befogenheter polisen får att operera dolt. Det finns också en fara för att gränserna mellan den som begår brott och dem som bekämpar dem i någon mån suddas ut eller blir oklar, om de senare i sitt arbete tillåts att begå brott. Även om polisen i sådana lägen strikt iakttar de riktlinjer som t ex riksdagen angett, är det möjligt att allmänhetens inställning till polisen på sikt skulle kunna påverkas i negativ riktning.

Ett annat helt centralt problem rör den $\mathrm{s} k$ överskottsinformationen. Bruk av moderna metoder som avlyssning och underrättelseförfarande leder till att polisen får del av och samlar mängder av upplysningar som rör andra än dem som misstänks för brott och annat än de misstänktas brottsliga verksamhet. Ibland kan man också, $\mathrm{t}$ ex vid telefonavlyssning, få kännedom om annan och mindre allvarlig brottslighet än den som föranlett beslutet om avlyssning. Hur skall man förfara med alla dessa upplysningar och hur skall man skydda integriteten för människor som inte har med brottsligheten att göra? 
Telefonavlyssning har stor betydelse vid utredning av bl a narkotikabrottslighet. Trots att det numera måste vara allmänt känt att samhället kan tillgripa denna åtgärd, fortsätter personer som är misstänkta för narkotikabrott att per telefon ha kontakter som kan bidra till att avslöja dem.

Det hänger säkert $\mathrm{bl}$ a samman med att telefonen kan vara svår att undvara när oförutsedda händelser inträffar eller eljest när man kommer i tidsnöd. Att medbrottslingar cmellanåt befinner sig på långa avstånd från varandra kan också göra telefonen oumbärlig för dem. Ibland är det inte heller vad som sägs vid kontakterna som är det värdefulla för polisen utan den omständigheten att vissa personer har kontakt med varandra vid en viss tidpunkt. Dessa förhållanden bidrar troligen till att telefonavlyssning - trots att det är en metod mot vilket man medvetet försöker värja sig - fortfarande har stort värde. Man bör trots integritetsfarorna inte avstå från detta redan etablerade tvångsmedel.

Gränserna för hur telefonavlyssning får begagnas sätts genom restriktiva lagregler och domstolsprövning. Dessa förhållanden anses värna kraven på integritet och garantera mot missbruk. Det finns även en annan omständighet som i praktiken också utgör ett visst skydd mot omfattande och mindre väl grundade ingrepp av detta slag. Telefonavlyssning är nämligen en synnerligen resurskrävande metod. För att den skall vara effektiv fordras att man - åtminstone tidvis - inte bara i efterhand lyssnar av de samtal som förts. För att de upplysningar man får skall kunna utnyttjas krävs ofta att man lyssnar kontinuerligt och att man dessutom hela tiden till sitt förfogande har polispersonal som kan sättas in för uppgifter som avlyssnade samtal ger skäl till. Man brukar räkna med att en effektiv telefonavlyssning fordrar ca sex dygnsarbetskrafter bara för själva avlyssningen. Därtill kan ofta komma behovet av $t$ ex tolkar och av poliser som omedelbart skall kunna agera med anledningen av vad man făr höra. Allt detta medför att telefonavlyssning på ett naturligt sätt begränsas till vad man vid varje tidpunkt anser vara de mest angelägna ärendena. Eventuella ändringar $\mathrm{i}$ regelverket $\mathrm{i}$ en »liberaliserande« riktning leder därför inte automatiskt till att avlyssningen också ökar i omfattning. För att det skall bli följden krävs dessutom att väsentligt mer personal sätts av för sådana arbetsuppgifter.

Telefonavlyssning får bara beslutas vid misstanke om mycket grova brott. Det kan emellertid hända att man vid avlyssningen får kännedom eller avgörande upplysningar om andra brott än det eller dem som legat till grund för beslutet om avlyssningen. Frågan är ifall polisen då får utnyttja denna $\mathrm{s} k$ överskottsinformation. Likartade problem kan uppstå vid andra metoder, $\mathrm{t}$ ex husrannsakan och brevkontroll.

Frågan om överskottsinformation är $\mathrm{f} n$ oreglerad i svensk rätt. Saken har emellertid varit aktuell $\mathrm{i}$ olika sammanhang (se t ex JuU 1976/77:28). Tvångs- 
medelskommittén skall enligt sina direktiv (dir 1975:57) se över frågan och föreslå en reglering.

Kommittén föreslog i betänkandet Hemlig avlyssning en lösning. Den gick i korthet ut på att informationen skulle fă begagnas, om den avsåg brott som var så grovt att det tvångsmedel med vars hjälp man hade fått upplysningarna - i det här fallet telefonavlyssningen - skulle ha kunnat begagnas även mot det brottet. Annars skulle polisen inte få utnyttja materialet (betänkandet s $64 \mathrm{ff}$ ). För att ta ett exempel: Om man vid avlyssning i samband med grovt narkotikabrott fick upplysningar om grova hälerier (minimistraff fängelse sex månader) eller rån (minimistraff fängelse ett år) skulle materialet inte fả begagnas, eftersom gränsen för telefonavlyssning går vid ett minimistraff på två år. Om det däremot avsåg våldtäkt (minimistraff fängelse två år) eller dråp (minimistraff fängelse sex år) skulle upplysningarna få tillföras utredningen.

Vid telefonavlyssning är man i en mening alltid ute efter vad som skulle kunna kallas överskottsinformation. Visserligen ligger misstanke mot en viss person om ett fullbordat brott till grund för beslutet om avlyssning. Men lika stort intresse torde knyta sig till att vid avlyssningen fă upplysningar om andra inblandade personer och förestående brott av samma slag som det som grundat avlyssningen.

Det är dock knappast sådana situationer som brukar avses när man talar om överskottsinformation. Man torde i stället i allmänhet mena upplysningar om helt andra brott än dem eller det som avlyssningen avsåg.

För vår del finner vi tvångsmedelkommitténs förslag något orealistiskt. Dels bygger det på att poliser som får veta något om ibland mycket grova brott, $\mathrm{t}$ ex rån eller organiserade hälerier, skall utplåna informationen ur minnet. Vi har svårt att se hur det skulle gå till. Dels förutsätter det att polisen medvetet skall avstå från att klara upp vissa brott för vilka de har möjlighet att få lagföring till stånd. Vi tror att det är föga lämpligt för polisens arbetsmoral. Detta desto mer som sådana regler verkligen utmanar til överträdelse.

Tvångsmedelskommitténs tidigare förslag har visserligen en del likheter med bevisregler som finns i andra länder, t ex USA. Om polisen där får upplysningar på olagligt sätt, kan åtal i princip inte bifallas för det brott dessa upplysningar avser. Sådana regler har sin bakgrund i de mycket strikta principer som gäller i övrigt om vilken bevisning som tillåts. Om t ex en polis griper någon utan att ha laglig grund för det och sedan vid kroppsvisitation hittar ett kilo heroin på denna, undgår personen lagföring. Liknande regler saknas dock i svensk rätt och ter sig också ganska främmande.

För vår del har vi svårt att se hur detta problem skulle kunna få en lösning som tillgodoser alla motstående intressen. Vi är närmast av den uppfattningen att, om man väl beslutat sig för avlyssning, polisen måste kunna utnyttja alla de 
upplysningar avlyssningen ger. I praktiken torde detta inte behöva leda till några stötande resultat. Man får räkna med att polisen $\mathrm{i}$ sådana situationer av prioriteringsskäl bara begagnar information om grövre brott och låter annat falla i glömska.

$\mathrm{Vi}$ vill med detta inte ha sagt att en sådan lösning är principiellt tillfredsställande. Den slutsats man enligt vår mening i stället skall dra är att tvångsmedel som kan försätta polisen i sådana här situationer, främst hemlig avlyssning, måsta begagnas med yttersta försiktighet och inte annat än om skälen för det är mycket starka.

Det görs ibland gällande att rätt för polisen till hemlig avlyssning med dolda mikrofoner avsevärt skulle förbättra möjligheterna att utreda grova brott och binda gärningsmännen vid brotten. Därvid medges att metoden är integritetskänslig men att den på den punkten inte på något avgörande skiljer sig från telefonavlyssning.

$\AA$ andra sidan hävdas att annan hemlig avlyssning än av telefoner inte bör införas i Sverige. Metoden skulle innebära ytterligare hot mot enskildas integritet - hot som dessutom på vissa punkter är värre än dem som telefonavlyssning medför.

Olika exempel brukar anföras på situationer där mikrofonavlyssning skulle vara värdefull. Ett är att polisen får veta att $t$ ex en leverantör och en distributör skall träffas på ett hotellrum för att göra upp en affär. Ett annat är att ett sammanträffande man gärna vill kontrollera skall äga rum på en restaurang. Slutligen har man talat om avlyssning av misstänktas bostäder och kontor eller andra arbetslokaler.

I alla sådana fall finns betydande praktiska svårigheter. Polisen måsta få tid och möjlighet att installera utrustningen innan de inblandade personerna kommer. Man måsta veta vilket hotellrum eller vilket restaurangbord som skall avlyssnass. Det förutsätter att personal som portier och hovmästare invigs $i$ planerna - vilket av flera skäl är mindre lyckat' - och att det verkligen är möjligt att styra de misstänkta till det rum eller det bord man önskar. De måsta helst också i förväg ha aviserat sin ankomst genom beställning e d. När det gäller avlyssnas. Det förutsätter att personal som portier och hovmästare invigs i planerna - vilket av flera skäl är mindre lyckat - och att det verkligen är möjligt att styra de misstänkta till det rum eller det bord man önskar. De måste helst också i förväg ha aviserat sin ankomst genom beställning e d. När det gäller avlyssning $\mathrm{i}$ bostäder, kontor o d är det extra svårt att anbringa och hämta tillbaka apparatur utan att den misstänkte eller någon närstående anar något. Till polisen begagnar. Detta kommer att gälla också hemlig avlyssning. På samma sätt som grova narkotikabrottslingar nu försöker anpassa sin verksamhet till 
möjligheten att telefoner är avlyssnade, kommer de att försöka gardera sig mot annan avlyssning.

1 praktiken finns det otal möjligheter att hindra att samtal kan avlyssnas. Uppfinningsrikedomen har dessutom visat sig vara mycket stor när det gäller att hitta medel mot polisens spanings- och utredningsmetoder. Det är troligen lättare att neutralisera mikrofonavlyssning än telefonavlyssning. Inget hindrar att man $\mathrm{t}$ ex skriver känsliga meddelanden till varandra på lappar eller genom att åstadkomma störande ljud - $\mathrm{t}$ ex rinnande vatten, radiomusik etc - effektivt hindrar avlyssningen. I sådana fali hindrar inte heller avlyssningen på samma sätt som vid telefonavlyssning att meddelanden över huvud taget utväxlas.

Som anfördes tidigare är troligen ett skäl till att telefonavlyssning fortfarande ger så stor utdelning att man i oförutsedda lägen eller när man befinner sig på långa avstånd från varandra inte kan undvara sådan kommunikation och därför blir oförsiktig. Mikrofonavlyssning har inte motsvarande styrka. Och den värdefulla information man kan få genom telefonkontroll, oavsett vad de inblandade säger, nämligen att de har kontakt med varandra, har man redan eller kan man lätt få genom andra spaningsmetoder när det är fråga om mikrofonavlyssning.

Det sagda utesluter inte möjligheten att man i vissa fall skulle kunna dra nytta av hemliga mikrofoner. Men det leder till ståndpunkten att dessa fall troligen är få, att de snabbt kommer att bli färre när det blir känt att metoden används samt att metoden är förenad med betydande praktiska problem. Man kan också befara en fortsatt ömsesidig teknisk upptrappning och att den långsiktiga vinsten i brottsbekämpningen blir liten.

Vad härefter gäller integritetshot och integritetsintrång är enligt vår mening annan hemlig avlyssning med mikrofoner och telefonavlyssning tämligen likartade. Båda metoderna medför också med nödvändighet att man kommer att lyssna på andra personer än dem som avses med beslutet om avlyssning och på annat än vad som rör brottslig verksamhet. Risken för att en domstol skall fatta beslut om oberättigad avlyssning är knappast större om beslutet avser mikrofoner än om det gäller telefoner. Medborgarnas grundlagsskydd är också detsamma mot båda företeelserna. Det finns dock framför allt en faktor som gör annan hemlig avlyssning något mer integritetskänslig än telefonavlyssning.

Hemlig avlyssning med hjälp av mikrofon innebär sålunda en mer total kontroll än telefonavlyssning. Man kan lyssna på allt som sägs - och även på annat än samtal - i den avlyssnade lokalen, vid alla tidpunkter på dygnet och oavsett vilka som vistas där. Allt som kommer inom mikrofonens räckvidd kan registreras. Det finns också anledning att anta att människor i allmänhet är något mer återhållsamma med vad de säger i telefonen än med vad de säger till varandra på tu man hand. Det är i och för isg en omständighet som skulle kunne an- 
föras för metodens effektivitet. Men det skulle också medföra att metoden är mer integritetskänslig än telefonavlyssning.

Argumentet att avlyssning med hjälp av mikrofoner bör tillåtas eftersom den inte utgör ett större integritetsintrång än telefonavlyssning kan också angripas från en annan utgångspunkt. Den omständigheten att den ena metoden används medför inte att den andra inte skulle innebära ytterligare faror. Att man har gjort undantag frán grundlagsskyddet på en punkt innebär ju inte att det blir ofarligt att göra undantag i ett annat avseende. Även om mikrofonavlyssning inte vore mer integritetskränkande än telefonavlyssning, leder möjligheten att använda båda metoderna till att summan av hoten mot integriteten ökar avsevärt. Det ena intrånget rättfärdigar knappast det andra, även om det senare inte skulle vara större än det första.

Till dessa invändningar kommer så vissa kontrollproblem som skiljer mikrofonavlyssning från telefonavlyssning. Det är i Sverige televerket som verkställer domstolens beslut om avlyssning. När det gäller telefonavlyssning kan polisen därför lätt värja sig mot obefogade anklagelser för omfattande och otillbörlig avlyssning eftersom ytterligare en myndighet är inkopplad. Genom denna extra kontroll blir det så gott som omöjligt att anordna telefonavlyssning utan vederbörligt tillstånd. Motsvarande naturliga kontroll av utomstående finns inte vid annan avlyssning. Även om man ställer upp stränga formella krav för att utnyttja avlyssningsapparatur, föreligger därför inte samma garantier mot missbruk eller påståenden om missbruk vid annan avlyssning som vid telefonavlyssning. Det vore synnerligen olyckligt, om misstanke uppstod att avlyssning kunde ske utan lagliga beslut. Blotta misstanken kunde äventyra allmänhetens tilltro till polisens arbete och över huvud taget få allvarliga följder för samhällsklimatet.

I ett öppet samhälle måste det finnas en gräns för de tvångsåtgärder som samhället är berett att vidta gentemot de enskilda medborgarna. Stora värden äventyras om samhället av olika skäl ständigt flyttar fram sin toleransgräns vad gäller tvångsmedel. En känsla - om än obefogad - av att ständigt kunna vara avlyssnad kan riskeras bli spridd bland medborgarna.

Till skillnad från avlyssning finns det inte något direkt skydd för den enskilde i svensk grundlag eller brottsbalk mot optisk övervakning. Den enda lagreglering som finns på området är lagen (1977:20) om TV-övervakning. Enligt den lagen får man inte använda TV-övervakningskamera utan att upplysa om det. När det gäller övervakning av plats som är upplåten för eller eljest nyttjas av allmänheten måste man dessutom ha länsstyrelsens tillstånd. Lagen gäller inte vissa kameror som används för att skydda anläggningar av betydelse för totalförsvaret. Det skall tilläggas att det står polisen fritt att under motsvarande omständigheter använda dold film- eller stillbildskamera eller att hålla en plats under uppsikt med hjälp av kikare. 
I förarbetena till lagen om TV-övervakning har emellertid framförts betänkligheter mot dold TV-övervakning. Sådan övervakning vore av flera skäl försåtlig för den som inte är medveten om dess existens. Dold TV-övervakning ansågs därför av integritetsskäl i princip inte böra få förekomma.

Från integritetssynpunkt är det givetvis vådligt att medborgarna mer allmänt kan bli föremål för övervakning från samhällets sida. Sådan övervakning kan av naturliga skäl inte begränsas till vissa personer och viss verksamhet. Den kan bidra till en obehaglig känsla av att ständigt kunna vara iakttagen och att inte veta när.

När det gäller polisens arbete att upprätthålla ordning och säkerhet är det inte någon nackdel att allmänheten får veta att TV-övervakning förekommer. Det är snarare så att det kan ha en positiv verkan. Det står emellertid också klart att polisen inte har någon som helst nytta av en TV-övervakning som inte är dold för att spana mot t ex narkotikahandel.

Men redan nu kan polisen använda sig av annan optisk utrustning för övervakningsändamål. Så sker också. TV-övervakning på en plats där man ändå alltid löper risk att iakttas med andra metoder kan enligt vår mening inte anses alttför integritetskränkande, även om den inte sker öppet.

Provokation är en av de mest omdiskuterade och kontroversiella metoderna för brottsbekämpning. Den ställer flera centrala principer och svåra gränsdragningar på sin spets. I vad mån är metoden möjlig att begagna utan att polisen själv begår brott och utan att man riskerar att polisen förmår andra att begå brott eller stimulerar till brott? Kan polisens trovärdighet $\mathrm{i}$ längden bibehållas om metoden kommer mer allmänt i bruk? Även om provokativa metoder inte är en ny företeelse, är det kampen mot narkotikan som under senare tid har gjort dessa frågor aktuella. Diskussionen om dem är internationell och har varit livlig inte minst $\mathrm{i}$ våra grannländer.

I Danmark och Norge godtas metoden under vissa förutsättningar. Möjligheterna får anses vara något större i Danmark än i Norge. ${ }^{1}$ Den norske riksadvokaten har slagit fast åtta regler för hur och när man får gå in som köpare $\mathrm{i}$ narkotikaärenden. Bland dessa kan nämnas att beslutet skall fattas på hög nivå och godkännas av åklagare, att misstanken skall vara stark, starkare än »skälig grund till misstanke«, att avsikten skall vara att ta en betydande mängd narkotika i beslag, att narkotikan i princip skall finnas i landet och skulle ha sålts till annan, om polisen inte hade gått in som köpare, att andra polismetoder skall vara uttömda och att enbart poliser skall kunna utföra provokationen.

1 Se t ex Dorenfeldt i Lov og Rett 1978 s 291-303 och Kallehauge i Ufr 1978 B s 85-91. I båda artiklarna refereras intressanta rättsfall. 
Det är svårigheten att åstadkomma tillräckliga bevis i vissa narkotikaärenden som lett till krav på att polisen skall få använda provokation. Det itypfall det är fråga om är ifall polisen skall ha rätt att gå in som köpare eller presumtiva köpare av narkotika och därigenom kunna skaffa handfasta bevis för innehav och försäljning av narkotika. Det finns dock varianter, och metoden ligger nära vad man brukar kalla infiltration och agentverksamhet.

Två principer står i fokus, nämligen att polisen för att uppdaga brott dels själv inte får begå brott, dels inte får någon att inleda en brottslig aktivitet. Är det, om dessa principer skall upprätthållas, över huvud taget möjligt att tillåta provokation, $\mathrm{t}$ ex i den formen att polisen köper narkotika?

Själva förvärvet och anskaffandet av narkotikan var inte straffbelagt enligt svensk rätt fram till den 1 juli 1983. Då trädde en rad ändringar av narkotikastrafflagen (1968:64) i kraft. Det straffbara området utvidgades avsevärt. $\mathrm{Bl}$ a kriminaliserades olovligt förvärv i överlåtelsesyfte och vissa fall av olovlig befattning med narkotika som inte varit avsedd för eget bruk. Som exempel på sådan olovlig befattning som kan vara straffbar anges i lagtexten bl a att någon anskaffar narkotika. Försök, förberedelse och stämpling samt medverkan·till dessa gärningsformer blev också straffbara.

Beträffande förvärv av narkotika i överlåtelsesyfte kan man säga att polisen givetvis inte har något syfte att överlåta narkotikan. Polisens syfte är att ta den i beslag. Denna nya gärningsform innebär således inte att polisen begår en kriminaliserad handling och utgör inte något hinder för polisen att använda köp av narkotika som spaningsmetod.

Frågan är då om den polis eller annan som på polisens uppdrag tar kontakt med en misstänkt narkotikaförsäljare och säger sig vara intresserad av att köpa narkotika gör sig skyldig till försök till en straffbar befattning med narkotika genom att söka anskaffa den. Detta torde knappast vara fallet. Den befattning som polisen i sitt polisarbete tar med illegal narkotika har aldrig ansetts olovlig och det finns ingenting som antyder att den nya regleringen skulle innebära någon förändring $\mathrm{i}$ detta hänseende. I själva verket går en stor del av polisens verksamhet ut på att »anskaffa« narkotika för att på så sätt förhindra att den missbrukas och omsätts illegalt. Den nya lagstiftningen torde alltså inte innebära någon ändring $\mathrm{i}$ fråga om i vad mån köp av narkotika utgör en tillåten spaningsmetod.

Härnäst gäller det att belysa om man, när provokation används, verkligen kan undgå att förmå människor att begå brott.

Ibland har man i svensk debatt försökt lösa detta problem genom att skilja mellan tillåten bevisprovokation och otillåten brottsprovokation. I det förra fallet skulle polisens provokation bara ge bevis om ett redan begånget brott och därmed vara godtagbar. 
Denna distinktion är dock enligt vår mening svårhanterlig. De argument som kan anföras mot den är både praktiska och teoretiska.

Typexempel för en bevisprovokation skulle vara när polisen tar kontakt med någon som man är övertygad innehar ett narkotikaparti för försäljning och ger sig ut för att vilja köpa partiet. Om man lyckas förmå den tänkte säljaren till affär, får man bevis om att denne innehar ett parti i försäljningssyfte.

För att detta skall stanna vid bevisprovokationen fordras till att börja med att polisen verkligen har rätt i sina misstankar och att det faktiskt förhåller sig så att personen innehar narkotika i försäljningssyfte. Problemet är alltså hur polisen skall kunna vara säker på det. Om polisen uppträder som köpare, finns det en risk för att en person de facto genom polisens åtgärder lockas till att begå ett brott. Polisen har $t$ ex misstankar om att en person handlar med narkotika. Det finns omständigheter som talar för att han har förvärvat och har tillgång till ett parti. Polisen går in som presumtiv köpare. När narkotikan skall överlämnas till polisen grips den misstänkte. Under utredningen kommer det fram att den misstänkte förvärvat narkotikan senare än polisen trodde och först på grund av att han tillfrågats av den person som på polisens uppdrag uppträdde som köpare. Något annat brott än det som provocerats fram av polisen kan i vart fall inte visas. Även om det finns skäl att misstänka att personen $\mathrm{i}$ fråga sysslar med narkotikahantering, så skulle han kanske inte ha begått just det här brottet, om han inte hade provocerats av polisen. Detta understryker betydelsen av att metoden i vart fall inte kommer till användning annat än om man verkligen är säker på att den som skall provoceras innehar narkotikan i försäljningssyfte.

Man skulle mot den bakgrunden då möjligen också kunna hävda att i de fall polisen med en tillräcklig grad av säkerhet vet att någon innehar narkotika i försäljningssyfte, skulle det vara möjligt att övertyga också domstolen om detta. I så fall vore bevisprovokationen inte nödig för att uppnå det man är ute efter, nämligen full bevisning.

Från rent praktiska utgångspunkter kan det resonemanget emellertid angripas på två sätt. För det första finns det ett mycket starkt intresse av att polisen făr fatt i narkotika som redan finns $\mathrm{i}$ landet och hindrar den från att komma ut på marknaden. Man kan tänka sig fall där det med till visshet gränsande sannolikhet står klart att någon har ett parti narkotika men där man inte vet var det finns. Det enda sättet att lägga vantarna på partiet kan då vara att gå in som köpare. För det andra kan det vara så att den bevisning man redan har är av den karaktären att den inte kan begagnas i domstol. Det är t ex väl känt att det - särskilt i narkotikamål - förekommer att personer av olika skäl, framförallt rädsla för repressalier, vägrar att vittna inför domstol om vad de är beredda att $\mathrm{i}$ 
hemlighet berätta för polisen. Detta kan visserligen i princip inte accepteras, och uppgifter som lämnas under sådana förbehåll måste bedömas med stor försiktighet. Men det hindrar tyvärr inte att man ibland hamnar i sådana situationer.

Slutsatsen av det här resonemanget är att gränsen mellan bevis- och brottsprovokation kan vara svår att iaktta innan själva provokationen äger rum men att det ändå finns starka skäl för att polisen i vissa fall skall ha rätt att gå in som köpare av narkotika. Det enligt vår mening viktigaste skälet är möjligheten att ta narkotika i beslag.

Det kan vidare med visst fog hävdas att det alltid blir en brottsprovokation om polisen går in som köpare av narkotika och därigenom förmår någon till en affär. Även om den man vänder sig till innehar ett narkotikaparti för försäljning, skulle nämligen aldrig affären med polisen ha kommit till stånd, om inte provokationen hade ägt rum. Det individualiserade brott som den försäljningen utgör har då provocerats fram av polisen och skulle aldrig ha begåtts utan provokation.

Mot detta kan å andra sidan göras gällande att det - i det renodlade provokationsfallet - är en tillfällighet att försäljningen sker till polisen och att den, om polisen inte hade gått in som köpare, skulle ha skett till någon annan. Visserligen skulle just det brott som blev följden av provokationen inte ha begåtts den förutan. Men gärningsmannen skulle ändå ha begått ett likadant brott. Även om det alltså vid en strikt bedömning är svårt att undgå slutsatsen att det alltid måste bli en brottsprovokation, kommer förfarandet inte att leda till att polisen förmår någon att begå ett brott han annars inte skulle ha begått.

Det sagda leder fram till att även om det individuella brottet i det tänkta exemplet aldrig skulle ha begåtts om inte provokationen hade ägt rum, så kan möjligen provokationen ändå godtas, trots att polisen förmått någon att begå ett brott. Hade polisen inte gått in som köpare, så skulle nämligen någon annan ha gjort det. Det måsta anses ha berott på tillfälliga omständigheter att försäljningen skedde till polisen och inte till någon annan. Vidare och det är ett synnerligen viktigt påpekande - går inte provokationen ut på att få fast någon för ett brott som provocerats fram utan för att få bevis om ett redan fullbordat brott, $t$ ex det tidigare förvärvet av narkotikan i överlåtelsesyfte.

Av det föregående kan den slutsatsen dras att provokation i form av köp eller föregivet köp av narkotika är en metod som i flera avseenden berör gränsen för vad man kan tillåta sig. Den bör likväl inte helt avvisas. De viktigaste skälen för att den skall få begagnas är att den kan vara det enda sättet dels att komma åt ett parti narkotika och hindra att det sprids, dels att 
få till stånd tillräcklig bevisning mot någons narkotikabrott. Metoden är emellertid synnerligen känslig. Det finns uppenbarligen risker för att man kan förmå någon begå brott som annars inte skulle ha begåtts. Metodens bruk kan leda till at polisen i andra sammanhang utsätts för beskyllningen att ha provocerat fram brott. Polisens eget agerande ligger åtminstone $\mathrm{i}$ närheten av gränsen för det straffbara området. Därtill kommer att metoden kan vara riskabel för de poliser som ger sig ut för att vilja köpa narkotika.

Mot denna bakgrund måste metoden begagnas med yttersta försiktighet. Polisen skall endast kunna använda köp av narkotika som metod att skaffa fram bevis i fall där det står klart att det finns ett visst parti narkotika i landet eller dess import är nära förestående. Detta parti skall kunna knytas till den person polisen tänker vända sig till med sitt bud om köp. Denna skall redan innan det sker vara på sannolika skäl misstänkt för ett fullbordat brott och för att inneha partiet för försäljning. Provokationen skall gå ut på att få bevis om detta brott och på att komma över partiet. Resultatet făr inte bli att den provocerade företar en försäljning han annars inte skulle ha gjort. Man måste undgå att komma $\mathrm{i}$ den situationen att endast kunna gå vidare med det brott som provocerats fram. Som regel bör ett åtal begränsas till att avse den brottslighet som ligger före provokationen, vanligen förvärv $i$ överlåtelsesyfte. Operationen bör avse att bevisa ett allvarligt brott eller att få tag i en större mängd narkotika, helst bådadera i förening.

Adress: Polismästare Hans Holmér

Poppelvägen 11 B

S-141 41, Huddinge. 